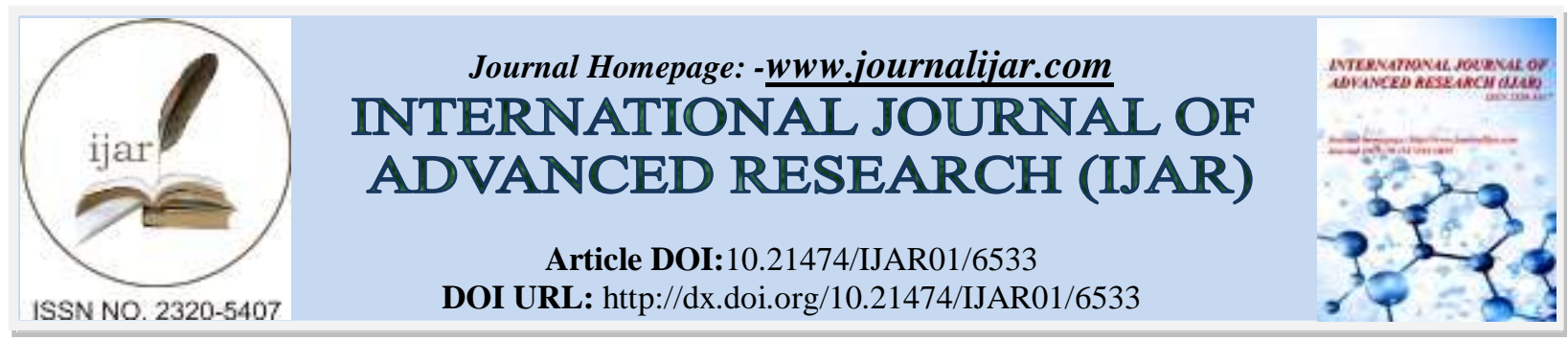

RESEARCH ARTICLE

\title{
CONTRIBUTION OF NEEM LEAVES IN RURAL LIVELIHOOD IN SOJAT CITY OF PALI DISTRICT IN RAJASTHAN.
}

Sangeeta Tripathi ${ }^{1}$ and Devendra Dhaka ${ }^{2}$.

1. Asstt. Chief Technical Officer, Arid Forest Research Institute, New Pali road, Jodhpur-342005.

2. Project Assistant, Arid Forest Research Institute, New Pali road, Jodhpur-342005.

\section{Manuscript Info}

Manuscript History

Received: 14 December 2017

Final Accepted: 16 January 2018

Published: February 2018

\begin{abstract}
Neem (Azadirachtaindica A. Juss) is the most useful medicinal plant in India and is popularly known as "Village Pharmacy". Each part of the neem tree has some medicinal property and is thus commercially exploitable. It is now considered as a valuable source of unique natural products for development of medicines against various diseases and also for the development of industrial products. Besides, green dried leaves of the tree are a good source of income to the farmers of Sojat in Pali district. A socio-economic survey was conducted in 103 villages in Pali district (Rajasthan) to assess the role of neem products in rural livelihood. Findings of survey revealed that trees are lopped only once a year (November-December). Neem leaf is traded commercially for mixing with Mehndi (Lawseniainnermis) by herbal industries and exported to various states viz. M.P., Maharashtra, Karnataka etc. as well as to various European and Gulf countries.Although it is a seasonal activity but provides employment for about 4-5 months (November-March) both for neem leave collectors, herbal and pharmaceutical industries. For rest of the year collectors and industrialists switch over to other employment opportunities. The gap between demand and supply of neem leaves is estimated as 100 ton/year in Pali district. On an average 150 ton neem leaf powder is also traded in India and abroad in the form of 80-100 kg packets at the prevailing rate of Rs.900/- per kg.Bailing of neem leaves is done at a rate of Rs.1/- per $\mathrm{kg}$ and $80 \mathrm{~kg}$ or $100 \mathrm{~kg}$ bales are prepared on job basis by M/s.Kamal Plastics, Sojat (Pali district in Rajasthan).
\end{abstract}

Copy Right, IJAR, 2018,. All rights reserved.

\section{Introduction:-}

Neem has been a beneficial tree to Indian farmers for many generations. It has a wide range of uses in agriculture, animal husbandry and the household level. Neem products can contribute to both the local and national economy and can provide a means of generating household income. Among the non-wood products, neem seed is the most commonly sold material (Hegde, 1993). The majority of neem seeds are crushed for oil, of which $95 \%$ is used for soap production with neem seed cake being produced and sold as a byproduct. The collection and sale of neem seed in India is based around an auction system, which has been running for 20-30 years (Ten Kate \& Laird, 1999), with seed being collected from wild trees on community lands or trees on owned land (Naiket al, 1999).

Corresponding Author:-SangeetaTripathi.

Address:-Asstt. Chief Technical Officer, Arid Forest Research Institute, New Pali road, Jodhpur- 
The price of the seed depends on the proximity to the market or processing unit as well as year to year variation in the quantity of seed available. An individual can collect up to $30 \mathrm{~kg}$ of neem fruits in a day. This equates to about 15 $\mathrm{kg}$ of seed with a total value of between Rs 60-150 (US\$1.45 - US \$3.60). The total amount of neem fruits collected annually in India is estimated to be $90,000 \mathrm{t}$, equivalent to about 45,000 t of seed. Neem tree owners may collect the fruits fallen under the trees themselves or allow others to do it. Those who collect fruits from other individuals' trees may pay an amount to the tree owner. In general, collection appears to be predominantly carried out by women, children and more marginalized groups. Processed and unprocessed seed is sold to the trader who takes the seed to a district level market. At market, seed may be sold to neem product manufactures (oil mills, pesticide manufacturers) or, where there is a high volume of trade, the seed is auctioned. Higher prices for seed can be obtained if the fruits are processed by removing the skin and pulp covering the seed and drying under shade, or are processed to produce seed kernels. Processing ensures better quality material, with higher azadirachtin content. The price of neem seed has been increasing (Jattanet al, 1995) and it has been suggested that factory owners in India are prepared to pay still higher prices for neem seed, but do not do so because of the poor quality of the seed collected (Jattanet al, 1995).

There are some studies which reveal that neem is not being exploited to its full potential by farmers, both in subSaharan Africa and south and south-east Asia (Ahmed, 1988; Moser, 1996). There appears to be a number of reasons for this, including a lack of knowledge surrounding neem's role in crop protection. Studies in Niger and Burkina Faso suggest that neem seed processing is cost effective if labour is not limiting, subsidies for commercial pesticides are removed and other neem products are also utilized (Marz, 1992; Ostermann, 1993).Hegde (1993) suggested that in India, little attention has been paid to the economics of neem use or to increasing the popularity of its cultivation. He also proposed that farmers could benefit from access to improved material, improved seed harvesting, processing and storage technology, improved extraction methods for on-farm use, and the development of local markets.

In Sojat city of Pali district in Rajasthan dry neem leaves are used in herbal industries and are mixed with Lawseniainnermis (Mehndi).

Material and Methods:-

Secondary Data Collection: Secondary data from different Govt, Agencies viz. District Statistical Department, Revenue Department, Forest Range offices of district, traders dealing with neem products, publications of other researchers etc. were collected.

Primary Data:-

Selection of Village: $10 \%$ villages with maximum population of neem trees were selected for detailed socioeconomic survey to assess role of neem and neem products in rural livelihood through semi-structured questionnaire. In total 103 were selected randomly for baseline socio-economic survey.

Field testing and updation of questionnaire: To assess the role of neem products in rural livelihood in Sojat city of Rajasthan, a questionnaire was prepared, tested in field and updated accordingly.

Result and Discussions: Findings of reconnaissance survey are described as under-

Pali is one of 33 districts of Rajasthan located between $24^{0} .75^{\prime}$ North latitude and $72^{0} .78^{\prime}$ East longitude. The district resembles an irregular triangle and has generally undulated plains with scattered hills. The Aravali range runs along the eastern side of the district from south-west to north-east.

The climate of the district is extreme in nature i.e. hot and dry in summer and cold in winter. Average temp.in summer reaches upto $42^{0} \mathrm{C}$ where as in winter it drops upto $8^{0} \mathrm{C}$. Normal annual rainfall in the district is 500 to 600 $\mathrm{mm}$.

Out of 103 villages surveyed in Pali district, The sampled households are mainly inhabited by Schedule Tribes, Schedule Cates and Other backward classes viz. Meghwals, Harijans, Damamis, Jogis, Kalbeliyas (SC), the Grasiyas, Bheels and the Meenas (ST) and the Kumhar, Rebari, Darjees (OBC). The General Households are the least in number consisting of the Rajputs, Jains and the Brahmins. As per 2011 census, total literacy rate is nearly $62.4 \%$. 
Agriculture is the main activity providing employment to $57.19 \%$ of the working population. Majority of the cultivators owned land in the size of 0-5 Bighas. The main Rabi Crops are wheat, Barley and oilseed, while Jawar, Maize, Bazra and cotton are the main Kharif crops. Farmers are progressive and a large number of them are adopting mechanized method of farming. However, most of the small and marginal farmers use bullocks for farming. Menhdi cultivation is practiced in Sojat city.

The secondary Occupation is live stock rearing. The climate is especially suitable for sheep and Goats. Hence, goat and sheep rearing is one of the very important livelihood source practiced by a large no. of BPL households belonging to Rebari Community.

The major chunk of the income under animal husbandry is from the sale of small animals like goats and sheep in particular but the market for live animals is not very developed and poorly organized. Vertical linkages between processors and livestock producers are quite rare. Market facilities are not available and even if in some places it is poorly maintained. Villagers mostly depend upon the middleman for sale of livestock and other forest products who charges commission to the tune of $20-30 \%$ of the marketing price. The dependency of livestock on tree fodder is high. The major fodder species includes: Azdirachtaindica, Prosopisjuliflora(pods)and P.cineraria, Acacia nilotica. The major fuel-wood supplier to poor section of the society is P.juliflora.

Average distance of a Bus stand from the sampled villages was about 6 Kilometres. DoosraDashakand God Vanda are the two main NGOs working on issues of Education and Watershed. Average distance of a Post Office and a Bank branch is about 9 Kilometres. Average distance of a Railway Station from the villages was about 13 Kilometres. Hand pump and Tanka are the two main source of domestic use of water. No village is having the facility of Electricity for agriculture in the Dhanis (Hamlet). Ground water on an average is available at a depth of 150 Feet.

Documentation on harvesting and trading of dry green neem leaves, fuelwood, wood and fruit in Pali district: 10 farmers were selected in Sojat city of Pali district in Rajasthan. Existing Neem trees in their fields were classified in different girth classes and lopped for collection of green leaves and fuel wood. The lopped portion of each tree was heaped near the tree in the ground and weighed to obtain fresh biomass. The heaps were then left for sun drying for about 15 days. After 15 days they were beaten by sticks to remove leaves.Except small trees (less than $45 \mathrm{~cm}$ diameter at breast height or DBH) $100 \%$ trees are lopped in the farmers field. The findings reveal that on an average yield of dry green neem leaves per tree (for each D.B.H. class interval) per year are $34.38 \mathrm{~kg}(45-60 \mathrm{~cm} \mathrm{DBH})$, $118.52 \mathrm{~kg}(61-75 \mathrm{~cm} \mathrm{DBH}), 122.33 \mathrm{~kg}$, ( 76-90 cm DBH), $151.53 \mathrm{~kg}(91-120 \mathrm{~cm} \mathrm{DBH}), 217.55 \mathrm{~kg}(121-$ $150 \mathrm{cmDBH}), 269.94 \mathrm{~kg}(151-200 \mathrm{cmDBH})$ and $381.63 \mathrm{~kg}(201 \mathrm{~cm} \mathrm{DBH} \mathrm{\&} \mathrm{above).} \mathrm{Dry} \mathrm{fuelwood/tree/year} \mathrm{was}$ estimated as $24.04 \mathrm{~kg}(45-60 \mathrm{~cm}$ DBH$), 85.33 \mathrm{~kg}(61-75 \mathrm{~cm} \mathrm{DBH}), 97.33 \mathrm{~kg}$, ( 76-90 cm DBH), $122.91 \mathrm{~kg}(91-120$ $\mathrm{cm} \mathrm{DBH}), 176.09 \mathrm{~kg}(121-150 \mathrm{cmDBH}), 224.00 \mathrm{~kg}(151-200 \mathrm{cmDBH})$ and $294.72 \mathrm{~kg}$ (201cm DBH \& above). Twothird of wood extracted from lopped material was accounted for fuel wood (Correction factor).

Fruits and Wood: Findings of socio-economic survey reveals that 100-150 ton fruits were collected and traded in the market at the prevailing rate Rs. 10-12/- per kg in Pali district. The wood is generally used for making household items viz. frames of doors and windows etc.

Tooth brush sticks: $43.5 \%$ uses toothbrush sticks of neem while remaining population uses toothpaste and toothpowder.

\section{Documentation of harvested and traded quantity:Pali District:}

Except small trees (less than $45 \mathrm{~cm}$ diameter at breast height or DBH)100 \% trees are lopped in the farmers field. The findings reveals that dry neem leaves yield per tree (for each D.B.H. class interval) per year are $34.38 \mathrm{~kg}$ (45-60 cm DBH), $118.52 \mathrm{~kg}(61-75 \mathrm{~cm} \mathrm{DBH}), 122.33 \mathrm{~kg}$, ( 76-90 cm DBH), $151.53 \mathrm{~kg}(91-120 \mathrm{~cm} \mathrm{DBH}), 217.55 \mathrm{~kg}(121-$ $150 \mathrm{cmDBH}), 269.94 \mathrm{~kg}(151-200 \mathrm{cmDBH})$ and $381.63 \mathrm{~kg}(201 \mathrm{~cm} \mathrm{DBH} \mathrm{\&} \mathrm{above).} \mathrm{Dry} \mathrm{fuelwood/tree/year} \mathrm{was}$ estimated as $24.04 \mathrm{~kg}(45-60 \mathrm{~cm} \mathrm{DBH}), 85.33 \mathrm{~kg}(61-75 \mathrm{~cm} \mathrm{DBH}), 97.33 \mathrm{~kg}$, ( 76-90 cm DBH), $122.91 \mathrm{~kg}(91-120$ $\mathrm{cm} \mathrm{DBH}), 176.09 \mathrm{~kg}(121-150 \mathrm{cmDBH}), 224.00 \mathrm{~kg}(151-200 \mathrm{cmDBH})$ and $294.72 \mathrm{~kg}$ (201cm DBH \& above). Twothird of wood extracted from lopped material is accounted for fuel wood. 


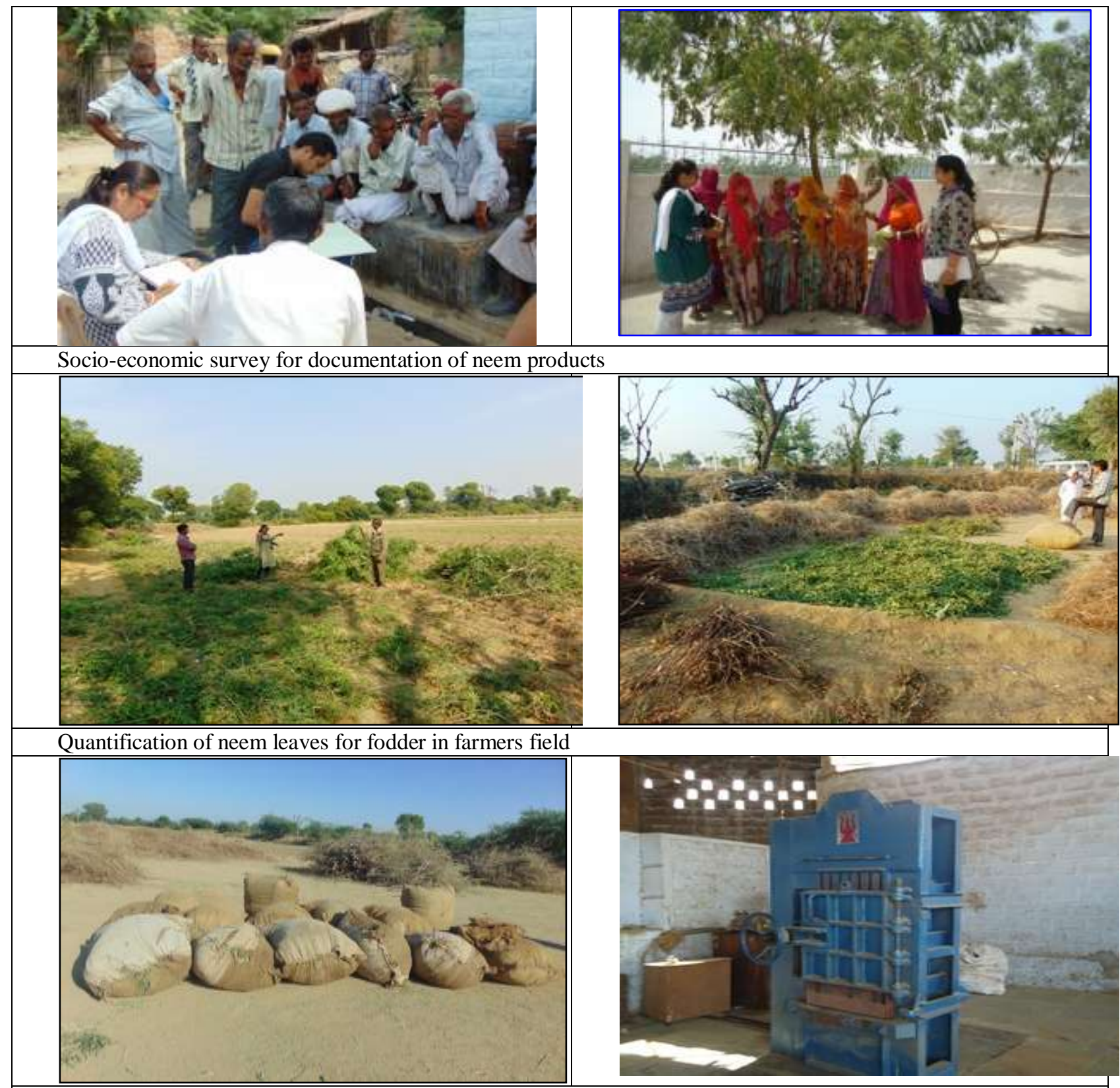

Packing of green dry neem leaves in farmers field for selling (Bailing machine)
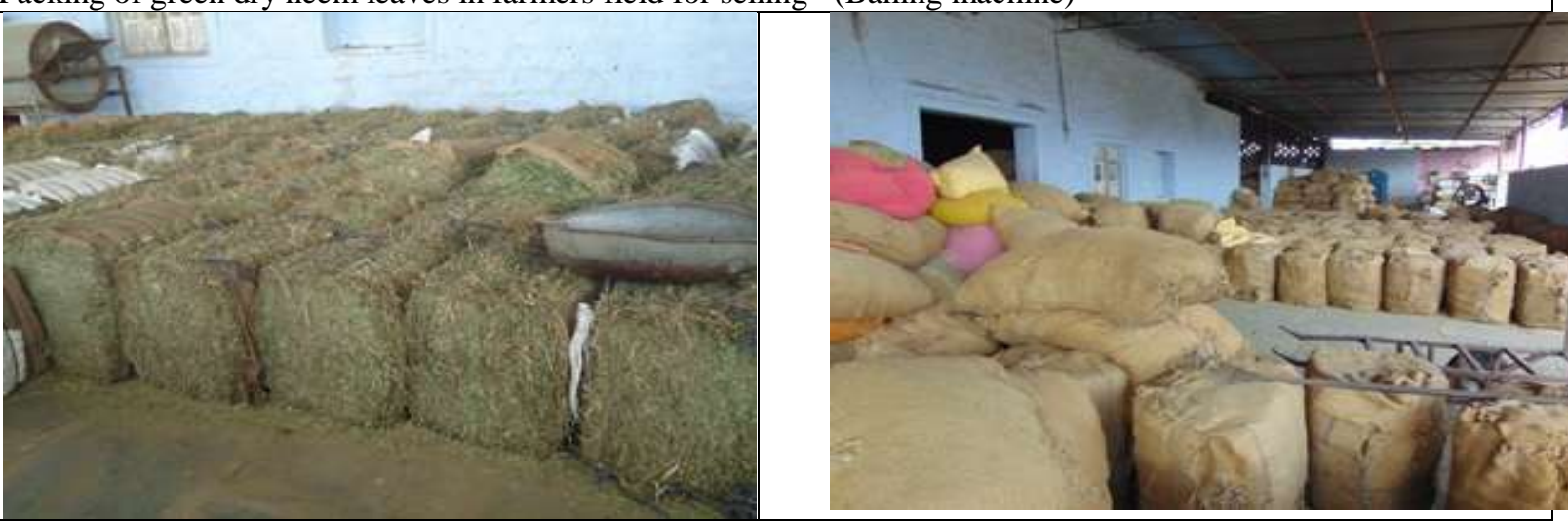

Storage of neem leaves after bailing in Sojat(Pali district in Rajasthan) 
Table-1: Dry Fodder and fuelwood yield ( Pali, Rajasthan)

\begin{tabular}{|l|l|l|l|l|}
\hline S.No. & DBH $(\mathrm{cm})$ & $\begin{array}{l}\text { Dry leaves yield/tree/ } \\
\text { year }(\mathrm{kg})\end{array}$ & $\begin{array}{l}\text { Dry fuelwood } \\
\text { yield/tree/ year }(\mathrm{kg})\end{array}$ & $\begin{array}{l}\text { Dry fuelwood yield/tree/ year }(\mathrm{kg}) \text { after } \\
\text { correction factor }\end{array}$ \\
\hline 1 & $45-60$ & 34.38 & 36.068 & 24.04 \\
\hline 2 & $61-75$ & 118.52 & 128.944 & 85.33 \\
\hline 3 & $76-90$ & 122.339 & 145.998 & 97.33 \\
\hline 4 & $91-120$ & 151.53 & 184.376 & 122.91 \\
\hline 5 & $121-150$ & 217.55 & 264.148 & 176.09 \\
\hline 6 & $151-200$ & 269.94 & 336.683 & 224.00 \\
\hline 7 & $>200$ & 381.63 & 442.086 & 294.72 \\
\hline
\end{tabular}

\section{Conclusion:-}

Due to its versatile uses in various fields viz. agriculture, veterinary, cosmetics, medicine, toiletries, saw mills, as fuel wood and fodder, neem is gaining very much attraction of villagers and industrialists in rural areas. Since, findings of the study reveal that it generates employment opportunities for rural masses. Therefore, apart from its natural regeneration, farmers use to plant new trees on their farm bunds to be utilized as a source of income in near future. Since, demand of Neem products are increasing day by day, it would be very fruitful for farmers to plant more and more neem trees in their fields .

\section{References:-}

1. Ahmed, S. (1988). Farmer pest-control practices in India: Some observations. Final Workshop of IRRIADBEWC Botanical Pest Control in Rice Based Cropping Systems, IRRI, December 12-16, 1988, IRRI, Los Banos, Philippines.

2. Hegde, N.G. (1993). Improving the Productivity of Neem Trees. World Neem Conference, Bangalore, India: 69-79.

3. Jattan, S.S. Kumar, S and Pujar, G. (1995). Margoculture: a vital component for plant health in the future. Indian Forester 121. 993-996.

4. Marz, U.(1992). The economic potential of an agroforestry system with neem (Azadirachtaindica) for small farms in the Sudano-Sahelian Zone of Burkina Faso. Der Tropenlandwirt. Zietschuftfur dieLandwirschaft in den Tropen and Subtropen 93: 23-28.

5. Moser, G.(1996). Status Report on Global Neem Usage. Pesticide Service Project, PN 86.2588.1. GTZ, Griesheim, Germany.

6. Naik, S., Daniel, J. Childs, F.J., Chamberlain, J.R. and Harris, P.J.C. (1999). Improvement of neem (Azadirachtaindica) and its potential benefits to poor farmers in developing countries - India Country Report. HDRA, Coventry, UK. 22

7. Osterman, H. (1993). Economic aspects of the use of neem products in vegetable production in Niger. Tropenlandwirt. 94: 13-20.

8. Ten Kate, K. and Laird, S.A.(1999). Crop protection. In: The Commercial Use of Biodiversity. Earthscan Publications Ltd., London, UK. 